\title{
浅析建筑工程造价影响因素及工程造价改善措施
}

\author{
胡金岗* \\ 中国黄金集团第三工程有限公司 河南 洛阳 471000
}

\begin{abstract}
摘 要: 随着时代的发展和进步, 我国市场经济体制也发生了很大的变化, 而市场经济体制的变化, 对建筑工程 的造价也产生了很大的影响, 这样的情况下, 建筑企业之间的竞争也更加的激烈。而工程造价是影响建筑工程市场竞 争的关键因素, 建筑企业在激烈的市场竞争中要想得到稳定的发展, 就需要不断地提升自身的市场竞争力, 而工程造 价是市场竞争的重要因素, 这就需要不断地提升工程造价管理和控制水平, 帮助企业降低成本, 获取更大的收益, 本 文主要分析了建筑工程造价影响因素及工程造价改善措施。
\end{abstract}

关键词：建筑工程; 造价影响因素; 改善措施

DOI: https://doi.org/10.37155/2717-557X-0207-2

引言

伴随社会的城市化发展, 建筑工程作为行业发展的重点, 通过造价管理方案的完善, 可以结合企业的运行特点, 设置完善性的管理方案, 实现经济化发展同时提升工程质量, 但由于建筑项目本身具有一定的特殊性, 存在着造价管 理不合理的问题, 在一定程度上影响施工进度, 无法发挥建筑工程项目的管理优势。因此, 在建筑工程行业运行中, 为了提高工程项目的施工质量, 施工单位要认识到造价管理的重要性, 通过施工进度、施工成本等内容的控制, 规范 建筑工程的施工行为，避免造价管理不足问题的出现，充分满足行业的持续发展需求。

\section{1 建筑工程造价管理的必要性}

根据建筑行业的运行状况, 造价管理特点如下: 第一, 在建筑行业运行中, 由于工程项目的规模逐渐增大, 施工技 术要求也相对较高, 在一定程度上增加了造价管理的难度。所以, 在造价管理中, 通过动态化造价方案的设定, 可以 在成本控制的同时控制施工进度, 满足建筑行业的经济化发展需求。第二, 根据建筑工程的项目特点, 造价管理一般 包括土地费用、原材料费用以及人工费用等, 这些费用设计范围相对广泛, 在造价管理中, 可以帮助企业根据工程项 目的特点, 设置完善性的管理方案，规范工程项目的管理行为，避免造价管理偏差问题的发生 ${ }^{[1]}$ 。

\section{2 影响建筑工程造价的因素}

\section{1 设计方面}

在现阶段建筑工程建设中, 设计图纸和设计方案都会对工程造价和其管理水平造成严重影响。特别是工程资料和 数据造假等问题, 会严重影响整个建筑工程的项目投资建设, 甚至会降低工程质量。因此设计人员在进行项目建设期 间, 需要全面考虑各项因素, 如经费问题、版面设计问题、施工建设材料问题和机械设备的运用问题等。另外建筑工 程财务人员还需积极做好预算工作, 进而精准地控制工程建设成本和造价。设计人员需要结合实际施工情况来详细计 算工程量, 将其计算的数据结果作为设计方案和图纸的重要来源与保障, 加强设计图纸与实际施工的一致性, 避免出 现数据误差, 影响施工质量。另外, 在建筑工程项目建设期间, 其场地的选择和工程规模的选择以及其各种装饰的布 置都会对工程造价有着一定的影响。

\section{2 建筑材料因素}

建筑工程施工, 需要使用大量的建筑材料, 而且建筑材料的车本在工程造价中占有较大的比例。一般来说, 结合 预算来进行材料的采购, 往往不会出现问题, 但是, 在采购材料的过程中, 需要保证材料的质量。不同的材料厂家, 所生产的材料在价格、质量方面均有所不同, 只有选择高质量、高性价比的材料, 才能避免出现重新购买的情况, 才 能减少成本的增加。而且材料在运输的过程中, 也有可能会有一定的损耗, 如果保证损耗控制在合理的范围内, 则不

*通讯作者：胡金岗，汉，1989.11.18，河南漯河，本科，工程师。研究方向：建筑工程。 
会增加造价成本，反之，则会给工程的造价带来很大的影响 ${ }^{[2]}$ 。

2.3 人员因素

工程造价与人员素质息息相关。在造价管理人员中，专业水平和工作经验存在十分明显的差异，预算不合理和造 价管理不达标的现象也较为普遍。部分造价管理人员在造价管理中并未做好考察工作, 并未对考察中存在的问题予以 全面、科学的分析, 最终工程预算方案与实际造价存在较大的差距, 引发了工程超预算问题。为此, 就有必要高度重 视造价人员专业技能的管理与规范，以此来全面发挥工程造价控制工作的作用。

\section{3 建筑工程造价改善措施}

3.1 建立健全的造价管理控制机制

建筑工程造价管理工作中, 需要采取有效措施建立完善的管理体系, 这也是工程造价管理工作得以顺利进行的重 要基础和前提, 创建科学的造价管理体系能够加强工程造价管控的实效性, 使其真正地应用在工程建设之中, 发挥出 工程造价管理的最大作用，从而巩固建筑企业的核心竞争力，使建筑企业在日后的建设和发展中处于有利位置。企业 发展中需将工程造价的管理控制作为首要任务, 并以此为基础, 合理利用覆盖面广泛的管理体系, 不断加强造价管控 的效果。科学的造价管理能够规范建筑工程各部门的日常工作, 密切多个部门间的沟通配合, 充分调动造价管理人员 的工作积极性，不断优化创新造价管理制度和方法。

\section{2 完善市场监督机制}

造价成本控制是建筑工程中必不可少的内容, 但是, 完善的市场监督机制也是十分重要的。一旦建筑市场出现变 化, 建筑工程的造价成本也会发生相应的变化, 所以, 建立完善的市场监督机制是非常有必要的, 通过完善的市场监 督机制来建筑市场进行科学、合理的管理, 避免出现恶意竞争, 为建筑市场营造良好的市场环境和氛围, 保证可以形 成公平公正的竞争局面, 并加强对工程造价的有效监督和管理, 保证企业在权益受到侵害时, 能够使用合法的手段维 护自身的权益，做到有法可依，这样才能实现建筑企业的长远发展。

\section{3 加强招标过程的工程造价控制}

首先需要结合工程的实际建设情况，对标底进行有效编制。其中标底主要是指工程的建设单位在减值过程中所提 出的投资项目, 一般标底都是以建设单位编制为主, 如果建设单位的条件不符合, 也可找寻一些其他符合资质的单位 进行辅助编制。同时在标底编制期间还需结合市场变动的情况, 实现综合与长远分析, 保障标底的编制质量, 合理控 制成本额度。其次需要明确的是, 在整个工程项目建设中招标阶段是重点, 特别是在合同签署和成本输人期间。因此 必须以公平公正的态度检查投标人的业务能力和生产经营状况, 对所有的投标单位创建公平竞争的环境。并且在选择 投标单位过程中不应当只关注工程建设成本, 还需要综合考量建设项目的质量与施工进度, 进而做出合理的分析, 保 障投标科学与合理性，进而为后续的工程造价控制奠定基础。

\section{4 强调造价管理中的成本控制}

根据建筑工程的项目特点, 造价管理中的成本控制是十分重要的。第一, 建筑工程项目管理中, 通过造价管理工作 的设置, 财务人员会根据工程项目的基本特点, 进行工程项目财务工作的分析, 逐步建立完善性的资料编制方案及归档 制度, 并要求施工人员按照资料规范进行工作, 避免施工偏差以及成本控制不合理问题的出现, 实现企业成本控制及造 价管理的目的; 第二, 在造价管理的成本控制中, 施工单位要认识到竣工结算的重要性, 通过项目的审查以及方案的研 究, 细化工程项目中的施工管理合同, 细化造价管理中的预算内容, 并通过成本金额、费用等内容的综合分析, 规范工 程造价管理方案, 为工程项目的成本控制及管理提供参考; 第三, 施工单位应该根据工程项目的基本特点, 合理安排施 工进度，保证工程项目顺利交付，避免由于工期延迟增加的成本支出，为单位经济化运作提供有效保障。

\section{5 提高造价管理人员的综合素质}

工程造价人员的专业素质对建筑工程造价管理的工作的高效落实具有较大的影响。因此, 建筑工程造价管理人员要 不断提升自身的专业素质, 熟练掌握建筑工程管理规范和法律法规。在工程管理中, 工程造价人员需基于自身现有的造 价管理经验，全方位展现自身的职能作用。企业招聘造价管理人员的过程中，应当结合企业自身发展趋势，适当提高招 聘门槛, 选择综合素质较高且经验丰富的工作人员。不仅如此, 企业在经营和发展中, 也可组织管理人员积极参与到培 训当中, 在系统培训后, 主动参加考核, 通过考核的人员方可投人到管理工作中。同时, 企业需结合实际建立完善的奖 
惩机制，鼓励造价人员主动学习专业的知识和技能，调动人员工作积极性，全面改善管理人员的综合素质。

\section{4 结束语}

综上所述, 在整个建筑工程造价管理中, 要想实现工程造价的合理控制, 就需要结合实际的工程设计情况、相关 合同管理和招投标管理办法, 将总工程造价控制在合理范围内, 保障整个施工顺利进行。

\section{参考文献:}

[1]王伟.影响建筑工程造价因素及降低工程造价的措施[J].城市建设理论研究,2019,(9):1-5.

[2]牟浩倩.浅析影响建筑工程造价因素及降低工程造价的措施[J].建筑与装饰,2020,(2):90. 